\title{
Effects of thermal process in bioactive compounds of mixed Brazilian cerrado fruit jam
}

Telma Melo BRANDÃO ${ }^{1}$, Elisângela Elena Nunes CARVALHO ${ }^{1}$, Juliana Pinto de LIMA², Eloá Lourenço do CARMO ${ }^{1}$, Heloisa Helena de Siqueira ELIAS ${ }^{1}$, Glêndara Aparecida de Souza MARTINS ${ }^{3 *}$, Soraia Vilela BORGES ${ }^{1}$ (D)

\begin{abstract}
The purpose of this study was to determine the effect of thermal vacuum processing and thermal processing without vacuum on the content of bioactive compounds and the antioxidant activity of low-calorie mixed Brazilian cerrado fruit jam. The mixed jam consisted of $60 \%$ of mixed pulp of Marolo, soursop and sweet passion fruit, and $40 \%$ other ingredients. This jam was utilized a completely randomized design to evaluate the antioxidant activity, total phenolic profile and content, carotenoid profile, and ascorbic acid content. The results showed that there was a reduction in bioactive compounds in the jam of $44.37 \%$ for total phenolics, $50.56 \%$ for ascorbic acid, $78.40 \%$ total carotenoids, and $65.14 \%$ for antioxidant activity when compared with the mixed pulps. In the carotenoid profile, reduction was observed for all compounds in relation to the mixed pulps, especially $\beta$-carotene (average loss of $81.89 \%$ ). Independent of the processing, there was a significant increase in $m$-coumaric acid in the jam compared with the mixed pulp. The concentrations of other phenolic compounds decreased after processing. These results suggest that thermal vacuum processing is most suitable for the production of jam with higher nutritional value.
\end{abstract}

Keywords: Annona muricata L.; Annona crassiflora Mart.; Passiflora alata Dryand; phenolic compounds.

Practical Application: Thermal process can be used to preserve bioactive compounds and antioxidant capacity in jams.

\section{Introduction}

Fruits are considered excellent sources of vitamins, minerals, fiber, carotenoids, antioxidants, and phenolic compounds; therefore, they are considered to have potential chemopreventive properties (Mahattanatawee et al., 2006). Vitamin C is an antioxidant naturally present in a daily diet; it has an anticancer effect and restores tocopherol to its active form in cell membranes by reducing the free radical form (Klimczak et al., 2007). Carotenoids present in the diet are bioactive and may confer beneficial effects on human health, such as decreased risk of degenerative diseases, prevention of cataract formation, reduction of age-related macular degeneration, and reduced risk of coronary heart disease (Krinsky, 1994). Phenolic compounds have antiallergic, anti-inflammatory, antimicrobial, antioxidant, antithrombotic cardioprotective, and vasodilatory properties (Giada \& Mancini-Filho, 2006). Therefore, consumption of fruits and vegetables is considered essential to human nutrition, not only because of the range of their benefits to the human body, but also because of their attractive flavor and texture.

Tropical fruits, such as Brazilian cerrado fruits marolo (Annona crassiflora, Mart), sweet passion fruit (Passiflora alata, Dryand) and soursop (Annona muricata, Linneaus), have attracted the interest of consumers owing to their exotic flavors and the wealth of bioactive compounds present in the pulp, peel, and seeds (Souza et al., 2012). However, fruits are seasonal and perishable and must be processed quickly to prevent deterioration and loss. They can be marketed in the form of jams, jellies, liquors, juices, ice cream, and nectars (Almeida, 1998).

The fruit pulp of marolo, sweet passion fruit and soursop in each $100 \mathrm{~g}$ contains: $85.47,58.51$ and 44.3 calories; $0.92,1.35$ and $0.6 \mathrm{~g}$ protein; $1.84,0.2$ and $0.1 \mathrm{~g}$ of lipids; $16.31,13.05$ and 9.84 of carbohydrates; $2.18,4.76$ and $2.22 \mathrm{mg}$ of calcium respectively. Although the content of $21 \mathrm{mg}$ of vitamin C present in the pulp of marolo is low, compared to other fruits native to the cerrado, it is still higher than that of some cultivated fruits, such as banana $6.4 \mathrm{mg}$ and apple $5.9 \mathrm{mg}$ (Souza et al., 2012; Almeida, 1998). The pulp of sweet passion fruit and soursop have good potassium levels 360 and $170 \mathrm{mg}$ respectively. The sweet passion fruit rich in alkaloid, flavonoids, carotenoids. The three pulps used in the formulation presented in his good constitution mineral content (iron, manganese and phosphorus) and vitamins A, B1, B2 and C (Almeida, 1998).

With respect to jams and jellies, a current trend is the production of foods with functional properties to satisfy the needs of consumers. These include low-calorie foods; foods with added nutrients or functional substances such as fiber, which may aid in disease prevention; and foods containing two or more fruits for enhanced nutrition and product differentiation (Singh et al., 2008). 
For the production of low-calorie foods and the addition of sucrose substitutes and functional compounds, heating is required to achieve the correct composition and other chemical, physical, and microbiological attributes. Two heating methods are used: an outdoor system (open pan) and a low-pressure (vacuum pan) or microwave system, which allow lower temperatures and shorter processing times (Igual et al., 2013), thus minimizing damage to the bioactive compounds present in fruits.

The use of high temperatures accelerates the degradation of antioxidants such as ascorbic acid, phenolic compounds, and carotenoids. In addition to having implications for disease prevention, this reduction of antioxidant capacity leads to the alteration of physical, chemical, and sensory attributes of the product through increased browning, loss of other nutrients, changes in texture, and other processes (Patras et al., 2011).

Therefore, this research aimed to evaluate the effects of thermal vacuum processing (TV) and thermal processing without vacuum (TWV) on the content of bioactive compounds (phenolic compounds, carotenoids, and ascorbic acid) as well as antioxidant capacity, beyond the profile of carotenoids and phenolic compounds, in mixed Brazilian cerrado fruit jam.

\section{Materials and methods}

\subsection{Pulp samples}

Marolo fruit and sweet passion fruit were purchased from Central State Supply (Contagem, MG, Brazil), transported to the Department of Food Science selected by degree of maturation, washed, and sanitized with $150 \mathrm{mg} . \mathrm{L}^{-1}$ of sodium hypochlorite for $15 \mathrm{~min}$. Already frozen soursop pulp was purchased from a commercial company. After sanitizing, fruits were processed in the Laboratory Pilot Plant, fruits were cleaned with tap water and separated into peel, seed, and pulp. Pulps were extracted manually with a knife and the husk and seed were discarded. The pulps were then homogenized in a blender and stored in sealed plastic bags in a cold room at $-18 \mathrm{mlC}$.

\subsection{Chemical reagents and additives}

The following chemicals were used in experiments: acetone, hydrochloric acid, 2,4-dinitrophenylhydrazine (2,4-DNPH), copper sulfate, ethanol, ether, Folin-Ciocalteu reagent (Sigma - Aldrich, Inc., St. Louis, MO, USA) sodium carbonate, gallic acid, methanol, petroleum ether, sulfuric acid, tert-butyl methyl ether, Celite, sodium chloride, anhydrous sodium sulfate, and glacial acetic acid. Water was purified on a Milli-Q system (Millipore, Bedford, MA, USA).

Phenolic standards were obtained as follows: gallic acid, (+)-catechin, chlorogenic acid, caffeic acid, vanillic acid, $p$-coumaric acid, quercetin, rutin, trans-3-hydroxy-4-methoxycinnamic acid, ellagic acid, trans-cinnamic acid, (-)-epicatechin, kaempferol, and rosmarinic acid were from Sigma Aldrich; ferulic acid, $o$-coumaric acid, and $m$-coumaric acid were from Fluka Chemie (Steinheim, Germany). For chromatographic analysis, samples and solvents were filtered through membranes with a pore size of $0.45 \mu \mathrm{m}$ (Millipore). Low-methoxyl pectin (LA210, Danisco), gum carrageenan, and locust bean gum were purchased from Danisco (Jundiaí, SP, Brazil); polydextrose and 3:1 sucralose/acesulfame-K from Nutramax (Catanduva, SP, Brazil); fructooligosaccharides (P95, Orafit) from Clariant (Belgium); citric acid from Nuclear (São Paulo, SP, Brazil); and potassium sorbate from Vetec (Rio de Janeiro, RJ, Brazil).

\subsection{Preparation of the jam}

To process the jams and mixed pulps (MP) was made according to Table 1. First homogenized MP (marolo, soursop, and sweet passion) was mixed with polydextrose. Then, low-methoxyl pectin, locust bean gum, and carrageenan, previously dissolved in $50 \mathrm{~mL}$ of water, were added and the mixture was heated to $60^{\circ} \mathrm{C}$. After, the fructooligosaccharides, dissolved 1:1 in water, were added to the jam. At the end of the process, citric acid, potassium sorbate, and sweeteners (sucralose and acesulfame K) were added and cooking was stopped immediately. The jam was processed in a boule with a thermal jacket (Maincal, Rosario, Argentina) under vacuum pressure (TV) at $550 \mathrm{mmHg}(73 \mathrm{kPa})$ and a temperature of $65-70{ }^{\circ} \mathrm{C}$. Similar processing conditions were used in the production tank with a mixer at ambient pressure (TWV) heated by a gas flame (Macanudo, SC, Brazil). The jam was then poured hot into $250-\mathrm{mL}$ sterile bottles, cooled in a container with water and ice, and stored in a climatic chamber at $\pm 25^{\circ} \mathrm{C}$ (Eletrolab, Brazil), and representative samples of the replicates for later analysis.

\subsection{Chemical analyses}

Chemical analyses of the samples, MP, and low-calorie mixed Brazilian cerrado fruit jam were performed in triplicate, and results are expressed on a dry weight basis $(\mathrm{dw})$.

\subsection{Preparation of antioxidant and total phenolic extracts}

Extracts were obtained according to the method described by (Larrauri et al., 1997). Briefly, samples were weighed (in grams) in centrifuge tubes and extracted sequentially with $20 \mathrm{~mL}$ of methanol/water $(50: 50, \mathrm{v} / \mathrm{v})$ at room temperature for $1 \mathrm{~h}$. The tubes

Table 1. Formulation of low-calorie mixed Brazilian cerrado's fruit jam.

\begin{tabular}{|c|c|}
\hline Ingredient & Concentration $(\%)^{*}$ \\
\hline $\begin{array}{l}\text { Mixed pulp ( } 20 \% \text { of marolo, soursop, and } \\
\text { sweet passion fruit pulp) }\end{array}$ & 60 \\
\hline Fructooligosaccharides (P95, Orafit $\left.{ }^{\circledR}\right)$ & 13.18 \\
\hline Polydextrose (Nutramax ${ }^{\oplus}$ ) & 23.16 \\
\hline Citric acid (Nuclear) & 0.20 \\
\hline Potassium sorbate $\left(\right.$ Vetec $\left.^{\circledR}\right)$ & 0.20 \\
\hline Low-methoxyl pectin $\left(\right.$ Danisco $\left.^{\circledR}\right)$ & 2.00 \\
\hline Locust bean gum (Danisco ${ }^{\circledR}$ ) & 0.61 \\
\hline Carrageenan gum $\left(\right.$ Danisco $\left.^{\circledR}\right)$ & 0.61 \\
\hline Acesulfame-K (Nutramax $\left.{ }^{\circledast}\right)$ & 0.01 \\
\hline Sucralose $\left(\right.$ Nutramax $\left.^{\oplus}\right)$ & 0.03 \\
\hline Total & 100 \\
\hline
\end{tabular}

*The concentration was based on the total weight before cooking. 
were centrifuged at $25,400 \mathrm{~g}$ for $15 \mathrm{~min}$, and the supernatant was recovered. Then, $20 \mathrm{~mL}$ of acetone/water $(70: 30, \mathrm{v} / \mathrm{v})$ was added to the residue at room temperature. The samples were extracted for $60 \mathrm{~min}$ and centrifuged. To determine the antioxidant activity as well as the total phenolic content and phenolic profile, the methanol and acetone extracts were combined and brought to a final volume of $50 \mathrm{~mL}$ with distilled water.

\subsection{Total phenolic content}

The total phenolic in the MP and the jam were determined using Folin-Ciocalteu reagent according to method (Waterhouse, 2002). The extract $(0.5 \mathrm{~mL})$ were mixed with $2.5 \mathrm{~mL}$ of Folin-Ciocalteau reagent $(10 \%)$ and $2 \mathrm{~mL}$ of sodium carbonate solution $(4 \%)$. The mixture was stirred and kept at room temperature for $2 \mathrm{~h}$ in the dark. The absorbance was measured at 750nm against a blank, aqueous solutions of gallic acid were used for calibration. The results are expressed as gallic acid equivalents (mg GAE / $100 \mathrm{~g} \mathrm{dw}$ ).

\subsection{DPPH radical scavenging capacity}

To obtain the extract, followed the same procedure used for the determination of total phenolic compounds. The DPPH free radical scavening capacity was estimeted using the method of (Rufino et al., 2010). The fruit and jam extracts $(0.1 \mathrm{~mL})$ were allowed to react with $(3.9 \mathrm{~mL})$ of the DPPH solution for $30 \mathrm{~min}$ in the dark, and the decrease in absorbance (ABS) was monitored with a spectrophotometer at $515 \mathrm{~nm}$. The radical-scavenging activity was expressed as \% of inhibition according to the Equation 1 (Lin et al., 2005).

Inhibition $(\%)=([$ A of control $-A$ of sample $] / A$ of control $) \times 100$

\subsection{Ascorbic acid}

The vitamin C content of MP and the jam were determined by a colorimetric method with 2,4-DNPH according to (Strohecker \& Henning, 1967). The samples were analyzed in a spectrophotometer at an absorbance of $520 \mathrm{~nm}$. The results are expressed as mg ascorbic acid/100 g.

\subsection{Carotenoid profile}

This analysis involved four steps: extraction of carotenoids, saponification, separation, and quantification by high-performance liquid chromatography (HPLC). The extraction of carotenoids was performed according to Rodriguez-Amaya (2001) and for saponification of carotenoids.

The separation of carotenoids was performed by HPLC using the method of Rodriguez-Amaya \& Kimura (2004) by using a high-performance liquid chromatograph (Waters) equipped with a W600 analytical pump, column oven, online degasser, 717 plus automatic injector, 2996 photodiode array detector (Waters), and YMC30 Carotenoid Column $(250 \times 4.6 \mathrm{~mm})$ (Waters). The mobile phase was methanol and phase B was tert-butyl methyl ether, and the program was as follows: $0 \mathrm{~min}$ $20 \%$ B; 30 s $25 \%$ B; 15 min $85 \%$ B; 15 min 5 s 90\% B; 16 min 50 s $90 \%$ B; $16 \min 55$ s $20 \%$ B; 28 min $20 \%$ B. The flow rate was $0.8 \mathrm{~mL} / \mathrm{min}$, the injected sample volume was $15 \mu \mathrm{L}$, the analysis time was $28 \mathrm{~min}$, and the chromatographic column oven temperature was $33^{\circ} \mathrm{C}$. The wavelength used was $450 \mathrm{~nm}$.

The carotenoids were quantified using external calibration curves were obtained from injections of five concentrations in duplicate and identified by comparing the retention times with those of pure standards (Rodriguez-Amaya \& Kimura, 2004).

\subsection{Phenolic profile}

HPLC analyses were performed using a Shimadzu chromatograph (Shimadzu Corp., Kyoto, Japan) equipped with four high-pressure pumps (model LC-20AT), a diode array detector (model SPD-M20A), degasser (model DGU-20A5), CBM-20A interface, CTO-20AC oven, and autosampler (model SIL-20A). Separations were performed using a Shimadzu Shim-pack GVP-ODS C18 column $(4.6 \times 250 \mathrm{~mm}, 5 \mu \mathrm{m})$ connected to a guard column (Shimadzu Shim-pack GVP-ODS C18, $4.6 \times 10 \mathrm{~mm}, 5 \mu \mathrm{m})$.

The mobile phase consisted of $2 \%(\mathrm{v} / \mathrm{v})$ acetic acid in water (mobile phase A) and 70:28:2 (v/v) methanol/water/acetic acid (mobile phase $\mathrm{B}$ ) at a flow rate of $1.0 \mathrm{~mL} / \mathrm{min}$ with a gradient elution program and a $65 \mathrm{~min}$ run time. The injection volume was $20 \mu \mathrm{L}$. Analyses were performed at $15^{\circ} \mathrm{C}$. The phenolic compounds were detected at $280 \mathrm{~nm}$.

Standard solutions were prepared in methanol and calibration curves were obtained from injections of five concentrations in duplicate. The phenolic compounds were identified by comparing the retention times with those of pure standards.

\subsection{Statistical analysis}

Utilized completely randomized design (DIC) and the results were analyzed by ANOVA and means were compared by Tukey test, at level of 5\%, using Sisvar software (Ferreira, 2003).

\section{Results and discussion}

The results for the determination of total carotenoids content, total phenolic content, ascorbic acid content and antioxidant activity (DPPH) are shown in Table 2 and all values are calculated on dry basis $(\mathrm{dw})$ and means of three replicats.

Total phenolic content varied from $4653.15 \pm 131.76$ to $2340.25 \pm 196.21 \mathrm{mg} \mathrm{GAE} / 100 \mathrm{~g}$ d.w. The loss of vitamin C was $46.8 \%$ and $54.3 \%$ for the jam processed by TV and TWV, respectively.

This work were detected losses of $83.01 \%$ and $80.67 \%$ for $\beta$-carotene, $92.57 \%$ and $83.63 \%$ for $\alpha$-carotene, $42.15 \%$ and $52.82 \%$ for 13 -cis- $\beta$-carotene, and $70.25 \%$ and $71.90 \%$ for 9 -cis- $\beta$-carotene in jam processed by TV and TWV, respectively, compared with the MP (Table 3 and Figure 1). It can be seen that the differences between processes were minimal, owing to the small variation in the processing temperature.

The Figure 2 illustrates the variation of the peak area percentage found for the MP, Jam TV and jam TWV main components that were identified and Table 4 present the major phenolic compounds identified in the MP and jam. 
Table 2. Bioactive compounds and antioxidant capacity of MP and low-calorie mixed Brazilian cerrados fruit jam for both types of processing (TV and TWV).

\begin{tabular}{lcccc}
\hline \multicolumn{1}{c}{ Material } & Carotenoids $(\mu \mathrm{g} / 100 \mathrm{~g})$ & $\begin{array}{c}\text { Total phenolics }(\mathrm{mg} \\
\text { GAE/100 g) }\end{array}$ & Ascorbic acid (mg/100 g) & DPPH (\% RSA) \\
\hline Mixed pulp & $1742.42 \pm 14.72^{\mathrm{a}}$ & $4653.15 \pm 131.76^{\mathrm{a}}$ & $123.2 \pm 20.86^{\mathrm{a}}$ & $43.52 \pm 1.28^{\mathrm{a}}$ \\
Jam TV & $379.81 \pm 36.72^{\mathrm{b}}$ & $2836.46 \pm 366.63^{\mathrm{b}}$ & $65.63 \pm 8.68^{\mathrm{b}}$ & $15.52 \pm 4.21^{\mathrm{b}}$ \\
Jam TWV & $372.58 \pm 58,5^{\mathrm{b}}$ & $2340.25 \pm 196.21^{\mathrm{b}}$ & $56.24 \pm 5.63^{\mathrm{b}}$ & $14.82 \pm 1.22^{\mathrm{b}}$ \\
\hline
\end{tabular}

Values followed by same letter within a column are not significantly different $(\mathrm{P}<0.05)$.

Table 3. Carotenoid profile (dry weight basis) of MP and low-calorie mixed Brazilian cerrado's fruit jam for both types of processing (TV and TWV).

\begin{tabular}{|c|c|c|c|}
\hline \multirow{2}{*}{ Carotenoid profile $(\mu \mathrm{g} / 100 \mathrm{~g})$} & \multicolumn{3}{|c|}{ Samples } \\
\hline & Mixed pulp & Jam TV & Jam TWV \\
\hline a-Carotene & $101.61 \pm 4.49^{\mathrm{a}}$ & $7.54 \pm 1.28^{c}$ & $16.63 \pm 5.35^{b}$ \\
\hline$\beta$-Carotene & $1381.11 \pm 18.89^{\mathrm{a}}$ & $234.55 \pm 26.41^{\mathrm{b}}$ & $266.91 \pm 35.6^{b}$ \\
\hline 13-cis- $\beta$-Carotene & $81.18 \pm 1.28^{\mathrm{a}}$ & $46.92 \pm 6.35^{b}$ & $38.26 \pm 6.21^{b}$ \\
\hline 9-cis- $\beta$-Carotene & $26.09 \pm 2.49^{\mathrm{a}}$ & $7.76 \pm 1.5^{b}$ & $7.33 \pm 1.80^{b}$ \\
\hline
\end{tabular}

Values followed by same letter within a column are not significantly different $(\mathrm{P}<0.05)$.

The flavonoid (+)-catechin had the highest concentration in the MP, followed by $m$-coumaric acid and chlorogenic acid. In both the TV-and the TWV-processed jam, the major compound was $m$-coumaric acid, followed by (+)-catechin, (-)-epicatechin, and chlorogenic acid. Most compounds were degraded by processing, except for (-)-epicatechin and $m$-coumaric acid. The concentration of $m$-coumaric acid was 7 times higher in the jam than in the pulp, regardless of the type of processing.

In this study, there was a decrease in total carotenoids of $78 \%$, compared with the MP, with both types of processing. This degradation may be attributed to several factors such as temperature, acidity, and the presence of light during the cooking process (Fennema, 2000). Other authors have reported carotenoid losses between $5 \%$ and $40 \%$, depending on the conditions of food preparation and preservation and the degradation (Igual et al., 2013). The degradation the products could be isomers of carotenoids or molecular fragments (Singh et al., 2008). Analysis of the total carotenoid content of the pulp of sapota jelly showed a loss of 97.5\% when compared with the fresh fruit, which was the highest loss found in a low-calorie mixed Brazilian cerrado fruit jam; despite these losses, sapota jelly could still suffice for the daily intake of vitamin A (Carvalho et al., 2012).

$\mathrm{TV}$ processing caused a smaller decrease in the total phenolic content (39\%), relative to MP, than TWV (49.7\%). The decreases in total phenolic content may be associated with the temperature used in the process and the presence of oxygen. Patras et al. (2011) reported that the reduction of total phenols during the cooking of strawberry jam may have been due to the disruption of cell structure and phenolic compounds nonenzymatic oxidation. They found that the phenolic contents of fruit and jam were $64.56 \%$ and $50.72 \%$, respectively, which corresponds to a loss of $21.43 \%$. Kalt (2005) reported that processing often damages antioxidants in fruits and vegetables. Maceration, heating, and various separation steps can result in oxidation, thermal degradation, leaching, and other events that lead to lower levels of antioxidants in processed foods compared with fresh foods.

Our results are in accordance with another study showing total phenolic losses of $20 \%$ or more during the processing of strawberries into jam (Amakura et al., 2000). Levaj et al. (2012) reported that processing of strawberries into jam decreased total phenols by $37-70 \%$; total phenol concentrations in jam samples varied between $212.78 \mathrm{mg} \mathrm{GAE} / 100 \mathrm{~g}$ d.w. for $\mathrm{cv}$. Miss and $383.19 \mathrm{mg}$ GAE$/ 100 \mathrm{~g}$ d.w. for cv. Madeleine. Kim \& Padilla-Zakour (2004) observed that the total phenolics on the basis of fresh fruits $(100 \mathrm{~g})$ generally decreased after jam making. The significant reduction of total phenolics ranged from $9 \%$ in cherry cv. Balaton jam to $27 \%$ in plum cv. BY 8158.50 jam.

Ścibisz \& Mitek (2009) compared the phenolic content in different highbush blueberry (Vaccinium corymbosum L.) jams (in relation to a dilution of fruit with sugar and water), and found that during the preparation of the jam, 7-17\% of the total phenolic content of the berries was lost. Although jams were made using the same procedure, the degree of loss of phenolic compounds depended on the ingredients.

The loss of vitamin C observed is probably due to the processing temperature, as temperatures in this range promote oxidative degradation of ascorbic acid by hydrolysis of the lactone of dehydroascorbic acid to form 2,3-diketogulonic acid (Fennema, 2000). Other factors such as light, $\mathrm{pH}$, oxygen, freezing, and water activity have an influence on the reaction kinetics (Fennema, 2000). Similar results have been reported in the literature for jellies of different strawberry cultivars, with losses of $65.9 \%, 46.0 \%$, and $37.7 \%$ reported for cv. Blink, cv. Polka, and cv. Senga, respectively (Mazur et al., 2014). Kim \& Padilla-Zakour (2004) found losses of $54.4 \%, 55.9 \%$, and $46 \%$ in jellies of cherry, plum, and raspberry, respectively.

Ramful et al. (2011) classified fruits into three categories according to the ascorbic acid content: low $(<30 \mathrm{mg} / 100 \mathrm{~g})$, 
medium (30-50 mg/100 g), and high ( $>50 \mathrm{mg} / 100 \mathrm{~g})$. According to this classification, both the MP (marolo, soursop, and sweet passion fruit) and the jams have a high ascorbic acid content.
The recommended daily intake (RDI) of ascorbic acid for adults is $(45 \mathrm{mg})$ so by eating about $20 \mathrm{~g}$ of mixed jam processed by TV or TWV, the consumer would get $19.5 \%$ or
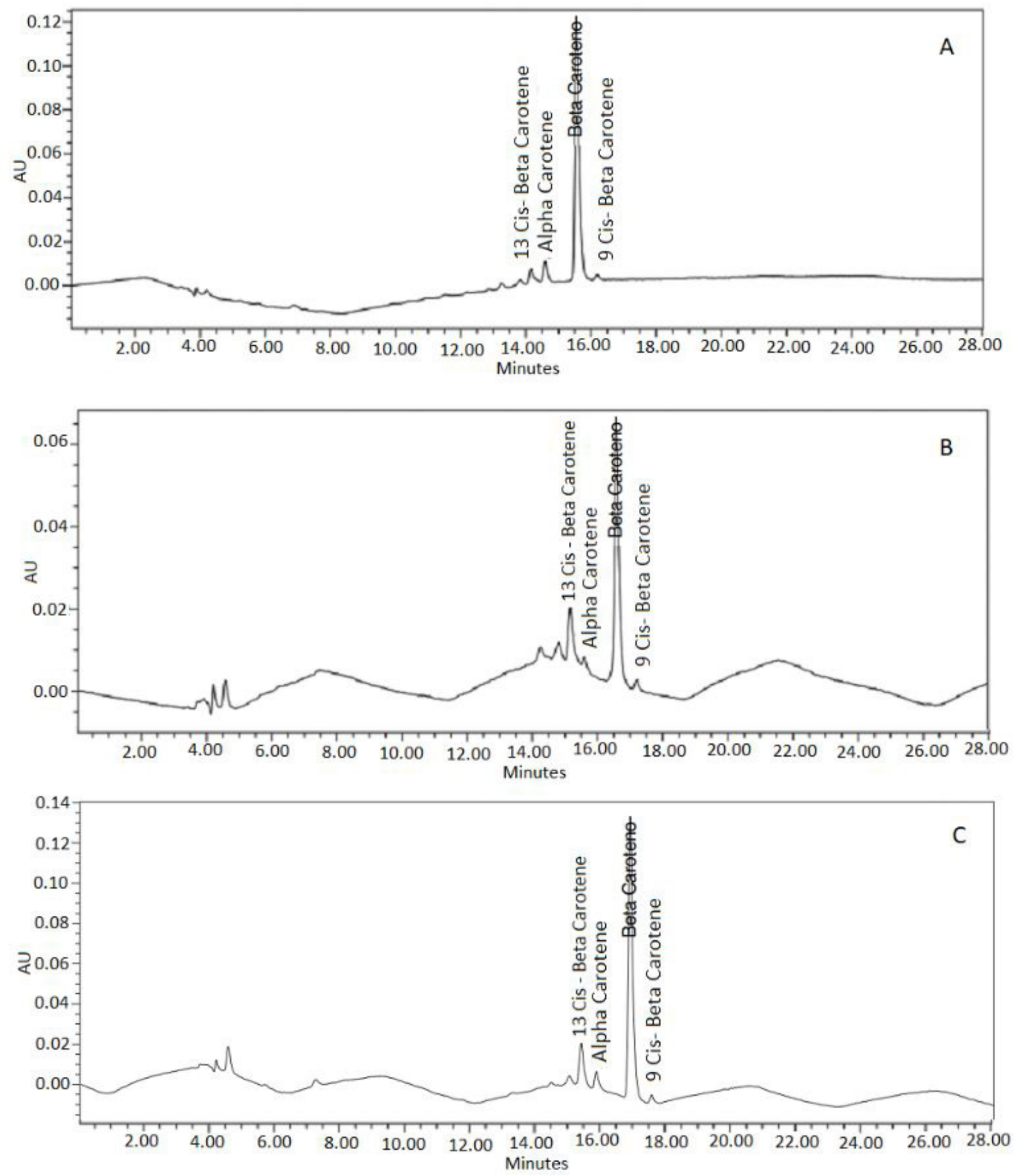

Figure 1. Chromatogram of carotenoid profile of MP (A) and mixed jam prepared by TV (B) or TWV (C). $1=13$-cis- $\beta$-carotene; $2=\alpha$-carotene; $3=\beta$-carotene; $4=9$ - cis- $\beta$-carotene. 
$16 \%$, respectively, of the RDI for vitamin C. According to the Brazilian legislation (Brasil, 1998) for a food to be considered a "high source" of vitamins, it must provide at least $30 \%$ of the
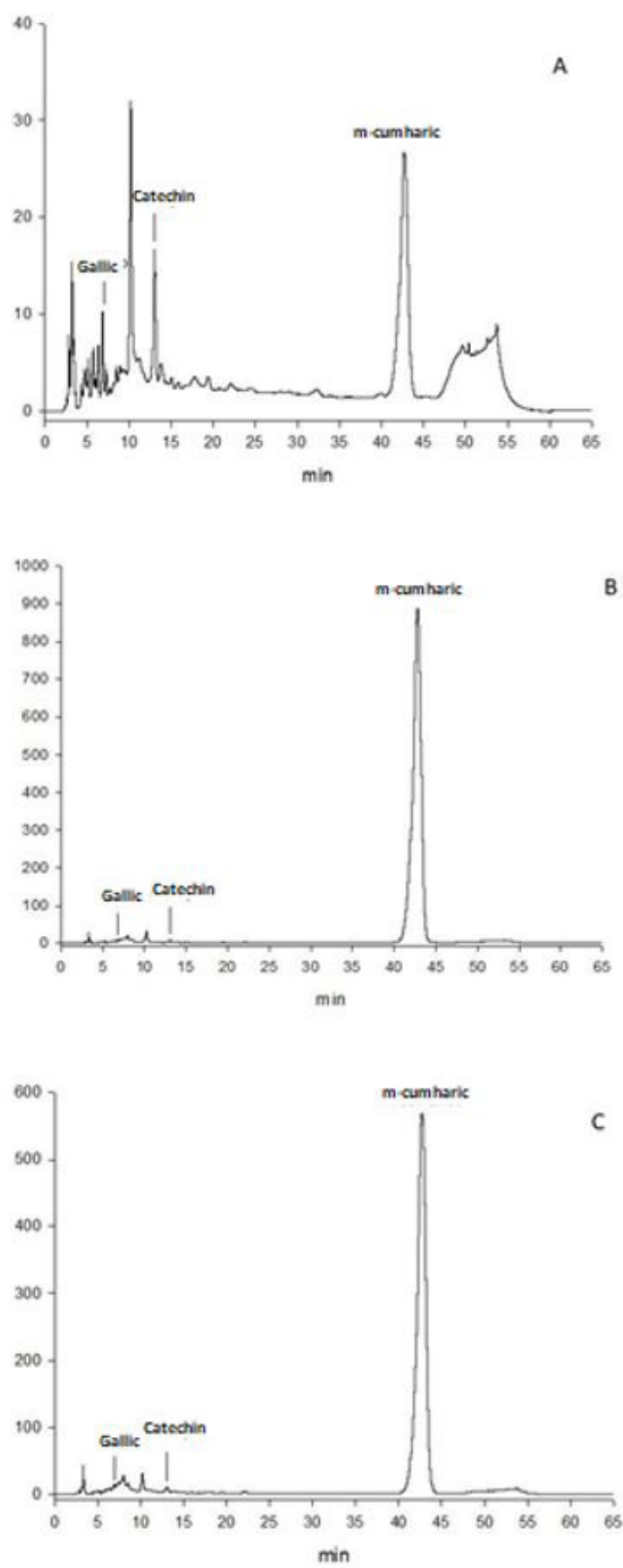

Figure 2. Chromatogram of phenolic compounds found in MP (A) and mixed jam prepared by TV (B) or TWV (C). 1 = gallic acid (6.85 min); $2=(+)$-catechin (13.03 $\mathrm{min}) ; 3=m$-coumaric acid (42.72 $\mathrm{min})$.
RDI per $100 \mathrm{~g}$. Mixed jam, regardless of the type of processing, can be considered a high source of vitamin $\mathrm{C}$, as it provides $97.5 \%$ or $80 \%$ of the RDI in a 100 g serving, which is 3.25 or 2.7 times higher than the level recommended by the legislation.

The main difficulty in measuring the antioxidant activity in foods is the choice of the method of analysis because typically the analysis is specific for only one property (Tlili et al., 2014). The average loss of antioxidant activity, compared with the MP, was $64.34 \%$ for the mixed jam processed by TV and $65.95 \%$ for the mixed jam processed by TWV. Therefore, this decrease is associated with the temperatures used in processing. The decrease may be attributable to the destruction of antioxidant compounds such as vitamin $\mathrm{C}$ and anthocyanins by the heating process during jam preparation (Kim \& Padilla-Zakour, 2004).

Hassimotto et al. (2005) classified the values of antioxidant activity as high (>70\% RSA), intermediate (40-70\% RSA), and low (<40\% RSA). Accordingly, the MP in our study can be classified as having intermediate activity and the jam, owing to losses of antioxidant compounds during processing, is classified as having low antioxidant activity.

Some authors have indicated that freezing, pasteurization, boiling, and microwave cooking generally reduce the antioxidant capacity of fruits (Singh et al., 2008). Processing of fruits normally leads to a decrease in the concentration and a change in the composition of phenolics, carotenoids, and vitamin $\mathrm{C}$ all of which have been described as antioxidant compounds. In this study, the decrease in antioxidant activity could be attributed to the reduction in the content of phenolic compounds, because the free radical scavenging activity (DPPH) is associated with substitution of hydroxyl groups in the aromatic rings of some phenolic compounds (Tlili et al., 2014).

Carotenoids are natural pigments with multiple biological functions. Many are provitamin A carotenoids, have effects on immune function, or have anticarcinogenic and antioxidant activities; therefore, in recent years these chemicals have aroused the interest of many researchers (Maldonade et al., 2008). The $\beta$-Carotene is the main precursor of vitamin $\mathrm{A}$ in the diet, and has antioxidant activity (Xu et al., 2006).

Similar changes either degradation or an increase have been observed in other studies of phenolic compounds subjected to thermal treatment (Agcam et al., 2014).

According to Fennema (2000) thermal energy is not the only factor that affects bioactive agents during processing. The use of acids in processing can promote the appearance of other phenolic compounds, for example by degrading anthocyanins to phenolic acids (Fennema, 2000). Therefore, it can be inferred that the combination of organic acids present in the fruit, citric acid used in the formulation, and processing temperature may have promoted the conversion of compounds derived from cinnamic acid (caffeic acid, trans-cinnamic acid, and trans-3-hydroxy-4methoxycinnamic acid) to $m$-coumaric acid via hydrogenation reactions and dehydroxylation (Farah et al., 2008).

It has been reported that the chlorogenic acid content of passion fruit pulp is $0.56 \mathrm{mg} / 100 \mathrm{~g}$ (Fu et al., 2011) and that caffeic acid and $p$-coumaric acid are present in soursop pulp 
Brandão et al.

Table 4. Phenolic profile of MP and low-calorie mixed Brazilian cerrado fruit jam (mg, $100^{-1} \mathrm{~g}$ d.w.).

\begin{tabular}{lcrr}
\hline \multicolumn{1}{c}{ Compound } & Mixed Pulp & Jam TV & Jam TWV \\
\hline Chlorogenic acid & $10.55 \pm 0.15^{\mathrm{a}}$ & $4.56^{\mathrm{b}} \pm 0.88^{\mathrm{b}}$ & $3.51 \pm 1.20^{\mathrm{b}}$ \\
Gallic acid & $1.92 \pm 0.07^{\mathrm{a}}$ & $0.28 \pm 0.04^{\mathrm{b}}$ & $0.29 \pm 0.05^{\mathrm{b}}$ \\
(+)-Catechin & $85.10 \pm 0.01^{\mathrm{a}}$ & $12.49 \pm 1.16^{\mathrm{b}}$ & $13.90 \pm 0.48^{\mathrm{b}}$ \\
$m$-Coumaric acid & $60.49 \pm 1.00^{\mathrm{b}}$ & $584.44 \pm 156.28^{\mathrm{a}}$ & $440.54 \pm 33.12^{\mathrm{a}}$ \\
(-)-Epicatechin & $5.40 \pm 0.14^{\mathrm{a}}$ & $6.32 \pm 0.65^{\mathrm{a}}$ & $6.56 \pm 0.17^{\mathrm{a}}$ \\
trans-Cinnamic acid & $0.23 \pm 0.05^{\mathrm{a}}$ & $0.05 \pm 0.02^{\mathrm{b}}$ & $0.05 \pm 0.02^{\mathrm{b}}$ \\
Caffeic acid & $2.63 \pm 0.07$ & $\mathrm{nd}$ & $\mathrm{nd}$ \\
trans-3-Hydroxy-4-methoxycinnamic acid & $3.60 \pm 0.06$ & $\mathrm{nd}$ & $\mathrm{nd}$ \\
\hline
\end{tabular}

Values followed by same letter within a column are not significantly different $(\mathrm{P}<0.05)$. nd = not detected.

(Leboeuf et al., 1980). Were observed that regardless of the phenolic compounds, phenolic concentrations in those studies were always higher than those found in the mixture of pulps analyzed in this study. Levels of gallic acid in black currant were $4-13 \mathrm{mg} / 100 \mathrm{~g}$; caffeic acid in kiwi, $60-100 \mathrm{mg} / 100 \mathrm{~g}$; chlorogenic acid and epicatechin in cherry, $18-115 \mathrm{mg} / 100 \mathrm{~g}$ and $5-22 \mathrm{mg} / 100 \mathrm{~g}$, respectively; and coumaric acid in plum, $14-115 \mathrm{mg} / 100 \mathrm{~g}$. These differences might be due to the chemical nature of each fruit and the fact that pulps were frozen until processing and suffered losses of phenolic compounds.

Kim et al. (2007) evaluated thermally treated ripe mangoes and identified gallic acid $(180 \mathrm{mg} / \mathrm{L})$ as the major phenolic compound and $p$-hydroxybenzoic acid, $m$-coumaric acid, $p$-coumaric acid, and ferulic acid as minor compounds.

Ignat et al. (2011) reported that the cinnamic acids (coumaric, caffeic, and ferulic acids) represented the major proportion of the phenolic content of strawberries and black currant; significant amounts of flavanols were also present.

Zadernowski et al. (2005) evaluated blueberries, black currants, and black mulberries in northeast Poland and found $m$-coumaric acid contents of 47.4, 187.29, and $28.55 \mathrm{mg} / 100 \mathrm{~g}(\mathrm{dw})$ and gallic acid contents of $9.36,7.23$, and $2.73 \mathrm{mg} / 100 \mathrm{~g}(\mathrm{dw})$, respectively. Palafox-Carlos et al. (2012) studied ripening stages of Ataulfo mango and found that gallic acid content ranged from 94.6 to $98.7 \mathrm{mg} / 100 \mathrm{~g} \mathrm{(dw)}$, while chlorogenic acid content varied from 28 to $301 \mathrm{mg} / 100 \mathrm{~g}(\mathrm{dw})$. Compared with the MP used in this study, the blueberries and black mulberries had lower concentrations of $m$-coumaric acid but higher concentrations of gallic acid. This shows the advantage of using a MP to obtain a product with a higher content of bioactive compounds.

\section{Conclusion}

The content of bioactive (total phenolics, vitamin C) and antioxidant activity (DPPH) compounds in low-calorie mixed Brazilian cerrado fruit jam was better preserved by TV processing than by TWV. However, there was no difference in total carotenoids or carotenoid profile between the two types of processing. Contents of some phenolic compounds, such as chlorogenic acid, (+)-catechin, and gallic acid, were reduced in the jam compared with the fresh MP, but the content of $m$-coumaric acid was higher after processing. These results suggest that the
TV process is a better method to preserve bioactive compounds and antioxidant capacity. The MP (marolo, soursop, and sweet passion fruit) and the low-calorie mixed jam, thermally processed with or without vacuum, can be categorized as having high concentrations of phenols and polyphenols.

\section{Acknowledgements}

The authors would like to thank the National Council for Scientific and Technological Development (CNPq) for granting research scholarships and for funding this project.

\section{References}

Agcam, E., Akyildiz, A., \& Evrendilek, A. (2014). Comparison of phenolic compounds of orange juice processed by pulsed electric fields (PEF) and conventional thermal pasteurization. Food Chemistry, 143, 354-361. http://dx.doi.org/10.1016/j.foodchem.2013.07.115. PMid:24054251.

Almeida, S. P. (1998). Cerrado: aproveitamento alimentar. Planaltina: EMBRAPA.

Amakura, Y., Umino, Y., Tsuji, S., \& Tonogai, Y. (2000). Influence of jam processing on the radical scavenging activity and phenolic content in berries. Journal of Agricultural and Food Chemistry, 48(12), 6292-6297. http://dx.doi.org/10.1021/jf000849z. PMid:11312801.

Brasil, Ministério da Saúde, Secretaria de Vigilância Sanitária. (1998). Aprova os níveis de Ingestão Diária Recomendada - IDR para vitaminas, minerais e proteínas (Portaria n 33 , de 13 de janeiro de 1998). Diário Oficial [da] República Federativa do Brasil.

Carvalho, V. C., Damiani, C., Asquieri, E. R., Orsi, D. C., \& Nishi, A. C. F. (2012). Development and Antioxidant Capacity of sapota pulp jelly (Quararibe cordata VISCHER). Ciência e Agrotecnologia, 36(3), 341-347. http://dx.doi.org/10.1590/S1413-70542012000300010.

Farah, A., Monteiro, M., Donangelo, C. M., \& Lafay, S. (2008). Chlorogenic acids from green coffee extract are highly bioavailable in humans. The Journal of Nutrition, 138(12), 2309-2315. http://dx.doi.org/10.3945/ jn.108.095554. PMid:19022950.

Fennema, O. R. (2000). Química de los alimentos (2. ed.). Zaragosa: Acríbia.

Ferreira, D. F. (2003). Sisvar: versão 4.2. Lavras: DEX/UFLA.

Fu, L., Xu, B. T., Xu, X. R., Gan, R. Y., Zhang, Y., Xia, E. Q., \& Li, H. B. (2011). Antioxidant capacities and total phenolic contents of 62 fruits. Food Chemistry, 129(2), 345-350. http://dx.doi.org/10.1016/j. foodchem.2011.04.079. PMid:30634236. 
Giada, M. L. R., \& Mancini-Filho, J. (2006). Importância dos compostos fenólicos da dieta na promoção da saúde humana. Publicatio UEPG. Ciências Biológicas e da Saúde, 12, 7-15.

Hassimotto, N. M. A., Genovese, M. I., \& Lajolo, F. M. (2005). Antioxidant activity of dietary fruits, vegetables, and commercial frozen fruit pulps. Journal of Agricultural and Food Chemistry, 53(8), 2928-2935. http://dx.doi.org/10.1021/jf047894h. PMid:15826041.

Ignat, I., Volf, I., \& Popa, V. I. (2011). A critical review of methods for characterization of polyphenolic compounds in fruits and vegetables. Food Chemistry, 126(4), 1821-1835. http://dx.doi.org/10.1016/j. foodchem.2010.12.026. PMid:25213963.

Igual, M., García-Martinez, E., Camacho, M. M., \& Martínez-Navarrete, N. (2013). Jam processing and storage effects on $\beta$-carotene and flavonoids content in grapefruit. Journal of Functional Foods, 5(2), 736-744. http://dx.doi.org/10.1016/j.jff.2013.01.019.

Kalt, W. (2005). Effects of production and processing factors on major fruit and vegetable antioxidants. Journal of Food Science, 70(1), R11-R19. http://dx.doi.org/10.1111/j.1365-2621.2005.tb09053.x.

Kim, D. O., \& Padilla-Zakour, O. I. (2004). Jam processing effect on phenolics and antioxidant capacity in anthocyanin-rich fruits: cherry, plum and raspberry. Journal of Food Science, 69(9), 395-400. http:// dx.doi.org/10.1111/j.1365-2621.2004.tb09956.x.

Kim, Y., Brecht, J. K., \& Talcott, S. T. (2007). Antioxidant phytochemical and fruit quality changes in mango (Mangifera indica L.) following hot water immersion and controlled atmosphere storage. Food Chemistry, 105(4), 1327-1334. http://dx.doi.org/10.1016/j.foodchem.2007.03.050.

Klimczak, I., Malecka, M., Szlachta, M., \& Gliszczynska-Swiglo, A. (2007). Effect of storage on the content of polyphenols, vitamin $\mathrm{C}$ and the antioxidant activity of orange juices. Journal of Food Composition and Analysis, 20(3-4), 313-322. http://dx.doi.org/10.1016/j.jfca.2006.02.012.

Krinsky, N. I. (1994). The biological properties of carotenoids. Pure and Applied Chemistry, 66(5), 1003-1010. http://dx.doi.org/10.1351/ pac199466051003.

Larrauri, J. A., Ruperez, P., \& Saura-Calixto, F. (1997). Effect of drying temperature on the stability of polyphenols and antioxidant activity of red grape pomace peels. Journal of Agricultural and Food Chemistry, 45(4), 1390-1393. http://dx.doi.org/10.1021/jf960282f.

Leboeuf, M., Cavé, A., Bhaumik, P. K., Mukherjee, B., \& Mukherjee, R. (1980). The phytochemistry of the Annonaceae. Phytochemistry, 21(12), 2783-2813. http://dx.doi.org/10.1016/0031-9422(80)85046-1.

Levaj, B., Kovačević, D. B., Bituh, M., \& Dragović-Uzelac, V. (2012). Influence of jam processing upon the contents of phenolics and antioxidant capacity in strawberry fruit (Fragaria ananassa $\times$ Duch.). Croatian Journal of Food Technology, Biotechnology and Nutrition, 7, 18-22.

Lin, Y. T., Vattem, D., Labbe, R. G., \& Shetty, K. (2005). Enhancement of antioxidant activity and inhibition of Helicobacter pylori by phenolic phytochemical-enriched alcoholic beverages. Process Biochemistry, 40(6), 2059-2065. http://dx.doi.org/10.1016/j. procbio.2004.07.019.

Mahattanatawee, K., Manthey, J. A., Luzio, G., Talcott, S. T., Goodner, K., \& Baldwin, E. A. (2006). Total antioxidant activity and fiber content of select Florida-grown tropical fruits. Journal of Agricultural and Food Chemistry, 54(19), 7355-7363. http://dx.doi.org/10.1021/ jf060566s. PMid:16968105.

Maldonade, I. R., Rodriguez-Amaya, D. B., \& Scamparini, A. R. P. (2008). Carotenoids of yeasts isolated from the Brazilian ecosystem.
Food Chemistry, 107(1), 145-150. http://dx.doi.org/10.1016/j. foodchem.2007.07.075.

Mazur, S. P., Nes, A., Wold, A. B., Remberg, S. F., Martinsen, B. K., \& Aaby, K. (2014). Effects of ripeness and cultivar on chemical composition of strawberry (Fragaria $\times$ ananassa Duch.) fruits and their suitability for jam production as a stable product at different storage temperatures. Food Chemistry, 146, 412-422. http://dx.doi. org/10.1016/j.foodchem.2013.09.086. PMid:24176361.

Palafox-Carlos, H., Yahia, E., Islas-Osuna, M. A., Gutierrez-Martinez, P., Robles-Sánchez, M., \& González-Aguilar, G. A. (2012). Effect of ripeness stage of mango fruit (Mangifera indica L., cv. Ataulfo) on physiological parameters and antioxidant activity. Scientia Horticulturae, 135, 7-13. http://dx.doi.org/10.1016/j.scienta.2011.11.027.

Patras, A., Brunton, B. P., Tiwari, B. K., \& Butler, F. (2011). Stability and degradation kinetics of bioactive compounds and color in strawberry jam during storage. Food and Bioprocess Technology, 4(7), 1245-1252. http://dx.doi.org/10.1007/s11947-009-0226-7.

Ramful, D., Tarnus, E., Aruoma, O. I., Bourdon, E., \& Bahorun, T. (2011). Polyphenol composition, vitamin C content and antioxidant capacity of Mauritian citrus fruits pulps. Food Research International, 44(7), 2088-2099. http://dx.doi.org/10.1016/j.foodres.2011.03.056.

Rodriguez-Amaya, D. B. (2001). A guide to carotenoid analysis in foods. Washington: ILST Press.

Rodriguez-Amaya, D. B., \& Kimura, M. (2004). Harvest Plus handbook for carotenoid analysis. Washington: IFPRI.

Rufino, M. S. M., Alves, R. E., Brito, E. S., Pérez-Jiménez, J., Saura-Calixto, F., \& Mancini-Filho, J. (2010). Bioactive compounds and antioxidant capacities of 18 non-traditional tropical fruits from Brazil. Food Chemistry, 121(4), 996-1002. http://dx.doi.org/10.1016/j.foodchem.2010.01.037.

Ścibisz, I., \& Mitek, M. (2009). Effect of processing and storage conditions on phenolic compounds and antioxidant capacity of highbush blueberry jams. Polish Journal of Food and Nutrition Sciences, 59(1), 45-52.

Singh, S., Jain, S., Singh, S. P., \& Singh, D. (2008). Quality in fruit jam from combinations of diferrent fruit pulps. Journal Food Processing and Prervetion, 33(S1), 41-57.

Souza, V. R., Pereira, P. A. P., Queiroz, F., Borges, S. V., \& Carneiro, J. D. S. (2012). Determination of bioactive compounds, antioxidant activity and chemical composition of cerrado Brazilian fruits. Food Chemistry, 134(1), 381-386. http://dx.doi.org/10.1016/j.foodchem.2012.02.191.

Strohecker, R., \& Henning, H. M. (1967). Analisis de vitaminas: métodos comprovados. Madrid: Paz Montalvo.

Tlili, N., Mejri, H., Yahia, Y., Saadaoui, E., Rejeb, S., Khaldi, A., \& Nasri, N. (2014). Phytochemicals and antioxidant activities of Rhus tripartitum (Ucria) fruits depending on locality and different stages of maturity. Food Chemistry, 160, 98-103. http://dx.doi.org/10.1016/j. foodchem.2014.03.030. PMid:24799214.

Waterhouse, A. L. (2002). Unit I1.1: polyphenolics: determination of total phenolics. In R. E. Wrolstad (Ed.), Current protocols in food analytical chemistry. New York: John Wiley \& Sons.

Xu, J., Tao, N., Liu, Q., \& Deng, X. (2006). Presence of diverse ratios of lycopene/b-carotene in five pink or red-fleshed citrus cultivars. Scientia Horticulturae, 108(2), 181-184. http://dx.doi.org/10.1016/j. scienta.2006.01.032.

Zadernowski, R., Naczk, M., \& Nesterowicz, J. (2005). Phenolic acid profiles in some small berries. Journal of Agricultural and Food Chemistry, 53(6), 2118-2124. http://dx.doi.org/10.1021/jf040411p. PMid:15769144. 